\title{
Brief Analysis on Investment Return of Data Warehouse Project of Commercial Bank
}

\author{
Leming Yang \\ School of Economics, Sichuan University, Chengdu, 610065, China
}

Keywords: commercial bank, data warehouse, investment return

\begin{abstract}
With the development of science and technology and the increasing demand of people, data warehouse technology has been gradually adopted by banks. Data warehouse project has the features of greater risk, longer investment period and instability. Therefore, it is necessary to plan well before investing to avoid blind investment. From the perspectives of interpretation of the definition of data warehouse project of commercial bank, investment return features of data warehouse project of commercial bank and qualitative and quantitative analysis of investment return of data warehouse project of commercial bank, the paper discusses the data warehouse project of commercial bank.
\end{abstract}

\section{Interpretation of Data Warehouse Project of Commercial Bank}

Data warehouse is the structure data environment of decision support system and analysis data source. It refers to the data set which can support the management decision process and face the theme, with the integration, stability and time change. The data warehouse system of the bank should first import the data from txt document into the source database, then transfer the data to the data warehouse, and then have the online analysis tool and data mining tool to carry out the statistical analysis and prediction function, so as to realize the function of supporting decision. The customer can query the information by the relationship between the dimension table and the corresponding fact table. The data mining algorithm can be used to extract the information, so as to predict the trend of the bank. At the same time, the customer's repayment ability and debt ability can be analyzed according to the known data.

\section{Analysis of Investment Return Features of Data Warehouse Project of Commercial Bank}

The data warehouse project of commercial bank has the characteristics of long-term, risk, instability and complexity. The analysis of the return characteristics of the commercial bank's data warehouse project cannot be only a simple profit and cost reduction. We should consider in the long run the combination of macro and micro factors and take full account of possible risks.

\subsection{Long-term Development Planning of Investment Return of Data Warehouse Project of Commercial Bank.}

The data warehouse is one of the most complex parts of the banking system. It integrates all the banking services, including a large number of bank data including customer's business information and other basic information, such as the ability to repay the debt. So the commercial bank data warehouse, as one of the main parts, will support the whole bank information department. The operation of the system helps the system to deal with the complex business and analyze it. With the change of business needs, the system can adjust and change its own time to meet the many needs of the customer. In the process of the continuous development of commercial bank data warehouse projects, the relationship between cost and income will inevitably change, which requires commercial banks to make a long-term plan for the bank data warehouse project, compare the annual bank data, and prepare the work before doing good things. As a result, the long-term goals and interests of the data warehouse project are put in the first place. We can not only pay attention to the small interests of 
the eyes and proceed from these aspects to analyze the investment returns of the commercial bank's data warehouse projects.

Table 1. Different Loan amount from 2014 to 2017

\begin{tabular}{|l|l|l|l|l|}
\hline Types of loans & $\begin{array}{l}\text { Loan amount } \\
\text { of 2014 }\end{array}$ & $\begin{array}{l}\text { Loan amount } \\
\text { of 2015 }\end{array}$ & $\begin{array}{l}\text { Loan amount } \\
\text { of 2016 }\end{array}$ & $\begin{array}{l}\text { Loan amount } \\
\text { of 2017 }\end{array}$ \\
\hline Car loan & 9800000 & 6100000 & 5600000 & 5500000 \\
\hline $\begin{array}{l}\text { Comprehensive } \\
\text { consumer loan }\end{array}$ & 5500000 & 8000000 & 9100000 & 9800000 \\
\hline Personal pledge loan & 1500000 & 6100000 & 4000000 & 7600000 \\
\hline $\begin{array}{l}\text { Micro Credit Loan for } \\
\text { short term }\end{array}$ & 8500000 & 8700000 & 8200000 & 9200000 \\
\hline Personal housing loan & 7500000 & 12000000 & 16000000 & 18000000 \\
\hline Sum & 32800000 & 40900000 & 42900000 & 50100000 \\
\hline
\end{tabular}

\subsection{Various Risks Analysis of Investment Return of Data Warehouse Project of Commercial} Bank.

The commercial bank data warehouse project, like other projects, has a certain risk, but unlike other projects, the risk of the data warehouse may only be static risk. It is impossible to have both static and dynamic risks like other investment projects, in other words, if the commercial bank data warehouse project takes place. Any risk will directly affect the profitability of commercial banks and affect the normal progress of projects. The risks of a data warehouse include business risks (the risks that the project cannot be effectively used), the risk of management (the risk of completing the project on time or in a specified time), the risk of the technology (the lack of team capacity, the risk that the technology does not play its role correctly), the organizational wind Risk (organization team personnel change, the construction project continues to normal operation caused great risk) and so on. In a word, any kind of risk will bring malpractice to the bank enterprise and cause the loss of profit. So before undertaking the project investment, we must take into account the risk of the return on the investment of the commercial bank's data warehouse project, carefully analyze it, try to reduce the risk from the small, and make the risk as small as possible. Control as far as possible within a suitable range, thereby bringing greater financial benefits.

\subsection{Multidimensional Analysis of Investment Return of Data Warehouse Project of Commercial Bank.}

Data warehouse itself is a complex aggregate, and many complex business and data analysis and processing are integrated. As the data warehouse is a continuous development and construction process, the long-term benefits of the data warehouse must be greater than the short-term benefits. Therefore, we should put an end to the mindset that is eager to gain the immediate benefit and ignore the long-term benefits. Only in this way, the better the better the project will be, the longer it will be. Benefits can be divided into two aspects: direct benefit and indirect benefit. The direct benefit is that the function provided by the data warehouse can reduce the labor cost for the bank and can improve the efficiency of the bank and other direct increase of the Bank benefits. It is considered as a direct profit. Indirect income refers to the use of the important information provided by the data warehouse system to improve the relationship with the customer, to reduce the cost, to improve the level of decision making, and so on, which is called indirect income. In fact, in some ways, indirect income is more valued by banks.

In a data warehouse, cost and income are corresponding, cost and income have both tangible and intangible points. The tangible cost refers to the visible costs, such as the cost of other related costs, such as the purchase, maintenance, repair and training costs of the equipment software, and the cost caused by the risk of wind, although it cannot be seen. But it does exist. This is intangible risk. 
Similarly, for the benefit of data warehouse, the important part of it is not the tangible profit of finance, but the invisible income. For example, the data warehouse project of commercial banks plays an important role in the reform and development of the whole financial information field. Therefore, it is necessary to carry out a multi-dimensional and three-dimensional analysis of the return on the investment of the commercial bank's data warehouse project, fully grasp the relationship between the cost and the income, do a good plan in advance, and carry out the scientific budget so as to make the big goal of the bank well realized.

\section{Qualitative Analysis of Investment Return of Data Warehouse Project of Commercial Bank}

\subsection{Analysis on Whether It Can Provide Better Service for Customers.}

The data warehouse can manage the customer relationship of commercial banks well and establish an integrated view of the relationship management. This view can make the bank master the basic situation of the customer. It can also carry on the analysis of the customer's product situation, transaction behavior, customer distribution and risk. Thus, we can have a better understanding of the customer, further strengthen the relationship between the bank and the customer, and maintain the relationship, which can keep the bank from the old customer to continue to maintain the income it brings, and ultimately achieve a better benefit.

\subsection{Analysis on Whether It Can Establish Good Internal Cooperative Relationships.}

In the commercial banks, each department, small to each person, has different roles in this big group and plays different functions. If there is no good communication and coordination between various departments, the phenomenon of cooperation and imbalance will have a negative impact on the bank, thus affecting its whole. In the competitiveness of the banking industry, the data warehouse provides the basis for the integration of various departments and the whole of the bank. The staff of each department can clearly understand their responsibilities and roles in the project. They can better coordinate their relationship with others, cooperate to complete the target tasks of the bank, and improve the efficiency and efficiency of the bank. Ability, through long-term joint efforts to achieve the bank's macro goals.

\subsection{Analysis on Whether It Can Improve Sensitivity of Banks to Market Changes.}

After a big wave of global integration, commercial banks are unpredictable in the international and domestic environment. In this environment, if the bank's information collection channels are narrow or the amount of information is small, it will directly affect the speed of the bank's reaction to the business market environment. In this case, the database can provide the bank with relevant information in time, including the related customer relationship, debt capability, asset ownership, financial situation and credit risk. It can contain information of different time period. The amount of information is large and more comprehensive. The best important thing is the timeliness and authenticity of the information. Reliability enables data warehouse to help banks react sensitively to market changes and take corresponding measures.

\subsection{Analysis on Whether It Can Strengthen Bank Data Management.}

For the bank, the data also has the macro and micro points. For macro data, it pays more attention to the overall grasp, considering the long-term goal of the bank, and the micro data is quite different. It pays more attention to the small data, that is, the details inside the bank, which is more difficult for the managers to grasp. At the same time, the data warehouse system can provide two polar views with high efficiency, which saves a lot of labor force, thus reduces the labor cost of the bank, avoids the decision error caused by the incomplete data analysis, and eventually increases the overall efficiency of the bank. 


\subsection{Analysis on Whether It Can Enhance Operation and Management Ability of Banks.}

The management capacity of banks is also an important factor that affects bank decisions and benefits. If the bank's operation and management capacity is not enough, it will surely shake the competitive position of banks and thus lose the efficiency of banks. The data warehouse here can easily handle the complex data of the bank, carry on the analysis of interest rate, liquidity analysis, analysis of assets and liabilities, analysis of customer contribution, income, cost and profitability analysis, which can effectively assist the decision making of the bank, which is beneficial to the manager. Risk control, so as to improve the management level of banks.

\section{Quantitative Analysis of Investment Return of Data Warehouse Project of Commercial Bank}

\subsection{Cost Analysis.}

The development cost of data warehouse consists of two parts: fixed cost and risk cost. The cost analysis is shown in Table 2.

Table 2. Cost analysis

\begin{tabular}{|c|c|c|c|}
\hline \multicolumn{2}{|c|}{ Project development cost } & \multicolumn{2}{|c|}{ Operation and maintenance cost } \\
\hline Hardware & $\mathrm{C}_{1}$ & $\begin{array}{c}\text { maintenance of Data } \\
\text { warehouse system }\end{array}$ & $\mathrm{C}_{6}$ \\
\hline Software & $\mathrm{C}_{2}$ & Database manager & $\mathrm{C}_{7}$ \\
\hline $\begin{array}{l}\text { Development } \\
\text { expense }\end{array}$ & $\mathrm{C}_{3}$ & System manager & $\mathrm{C}_{8}$ \\
\hline Cost of HR & $\mathrm{C}_{4}$ & Network manager & $\mathrm{C}_{9}$ \\
\hline \multirow[t]{2}{*}{$\begin{array}{l}\text { Innovation } \\
\text { expense }\end{array}$} & $\mathrm{C}_{5}$ & Trainers & $\mathrm{C}_{10}$ \\
\hline & & $\begin{array}{l}\text { Maintenance cost of } \\
\text { hardware and } \\
\text { software }\end{array}$ & $\mathrm{A}\left(\mathrm{C}_{1}+\mathrm{C}_{2}\right)$ \\
\hline $\begin{array}{c}\text { Sum of } \\
\text { development cost }\end{array}$ & $\begin{array}{c}\mathrm{C}_{1}+\mathrm{C}_{2}+\mathrm{C}_{3}+\mathrm{C}_{4} \\
+\mathrm{C}_{5}\end{array}$ & $\begin{array}{c}\text { Sum of maintenance } \\
\text { cost }\end{array}$ & $\begin{array}{c}\mathrm{C}+{ }_{6} \mathrm{C}_{7}+\mathrm{C}_{8}+\mathrm{C}_{9}+\mathrm{C}_{10}+\mathrm{A}( \\
\left.\mathrm{C}_{1}+\mathrm{C}_{2}\right)\end{array}$ \\
\hline Sum of fixed cost & \multicolumn{3}{|c|}{$\mathrm{C}_{1}+\mathrm{C}_{2}+\ldots+\mathrm{C}_{10}+\mathrm{A}\left(\mathrm{C}_{1}+\mathrm{C}_{2}\right)$} \\
\hline Risk cost & \multicolumn{3}{|c|}{$\mathrm{B}\left[\mathrm{C}_{1}+\mathrm{C}_{2}+\ldots+\mathrm{C}_{10}+\mathrm{A}\left(\mathrm{C}_{1}+\mathrm{C}_{2}\right)\right]$} \\
\hline Total cost & \multicolumn{3}{|c|}{$(1+B)\left[C_{1}+C_{2}+\ldots+C_{10}+A\left(C_{1}+C_{2}\right)\right]$} \\
\hline
\end{tabular}

In the course of the project, there may be a variety of reasons for the lack of a project in a certain aspect, and it needs to be adjusted in time. These problems are difficult to avoid completely for the data warehouse. In advance, we should plan closely the project and formulate a series of countermeasures to ensure the smooth progress of commercial bank data warehouse project investment.

\subsection{Benefit Analysis.}

The direct income of the data warehouse mainly lies in the saving of the cost of human resources. The database can also provide accurate information, which is convenient and accurate. It has brought great convenience to the bank. To a certain extent, it has raised the efficiency of the bank and also increased the income of the bank. 
Table 3. Benefit analysis

\begin{tabular}{|c|c|c|c|l|c|}
\hline \multicolumn{2}{|c|}{ Direct income } & \multicolumn{4}{c|}{ Indirect income } \\
\hline \multirow{2}{*}{$\begin{array}{c}\text { Human } \\
\text { benefit }\end{array}$} & \multirow{2}{*}{$\mathrm{B}_{1}$} & $\begin{array}{c}\text { Customer } \\
\text { department }\end{array}$ & $\begin{array}{c}\text { Analysis of } \\
\text { customer } \\
\text { relations }\end{array}$ & $\begin{array}{c}\text { Increase customer } \\
\text { loyalty and } \\
\text { customer value }\end{array}$ & $\mathrm{B}_{3}$ \\
\cline { 2 - 6 } & & $\begin{array}{c}\text { Assets and debt } \\
\text { department }\end{array}$ & $\begin{array}{c}\text { Analysis of } \\
\text { Assets and debt }\end{array}$ & $\begin{array}{c}\text { Grasp the change } \\
\text { trend of assets } \\
\text { and liabilities }\end{array}$ & $\mathrm{B}_{4}$ \\
\hline \multirow{2}{*}{$\begin{array}{c}\text { Efficiency } \\
\text { improvement }\end{array}$} & $\mathrm{B}_{2}$ & $\begin{array}{c}\text { Financial } \\
\text { department }\end{array}$ & $\begin{array}{c}\text { Analysis of } \\
\text { financial } \\
\text { department }\end{array}$ & $\begin{array}{c}\text { Decrease } \\
\text { operation cost }\end{array}$ & $\mathrm{B}_{5}$ \\
\cline { 2 - 6 } & \multicolumn{2}{|c|}{$\begin{array}{c}\text { Risk } \\
\text { management } \\
\text { department }\end{array}$} & $\begin{array}{c}\text { Analysis of } \\
\text { credit risk }\end{array}$ & $\begin{array}{c}\text { Improve pre-loan } \\
\text { rate analysis and } \\
\text { ensure quality }\end{array}$ & $\mathrm{B}_{6}$ \\
\hline \multicolumn{2}{|c|}{ Sum of benefit } & \multicolumn{4}{|c|}{$\mathrm{B}_{1}+\mathrm{B}_{2}+\mathrm{B}_{3}+\mathrm{B}_{4}+\mathrm{B}_{5}+\mathrm{B}_{6}$} \\
\hline
\end{tabular}

\section{Conclusion}

Data warehouse, as a symbol of the development of science and technology in the new era, has increased the effectiveness of commercial banks to a certain extent. For the investment of commercial bank data warehouse project, we must have a cool attitude. We should neither be too optimistic nor too pessimistic. Data warehouse projects are complex, with long investment cycle, high risk and instability. To overcome the shortcoming of blind investment, we must make a good investment plan. Only in this way can commercial banks' data warehouse projects benefit the banks and the country.

\section{References}

[1] Xia Hongxia, Zhao Yang, Cao Xianyuan, et al. Study and Improving on Hierarchical Arithmetic of Association Rule [J]. Journal of Wuhan University of Technology, 2000, 22(5): 79-82.

[2] Wang Jianzhong, Zhang Hui, Wu Bin, et al. Image-Denoising Method Based on Daubechies Wavelet Transform andMedian Filter [J]. Journal of Wuhan University of Technology, 2001, 22(5): 79-82.

[3] Wang Xiaoqun. Application of Information Discovery Method in Demand Analysis of Bank Data Warehouse System [J]. Computer and Information Technology, 2017, 25(1): 56-58.

[4] Zhang Yan, Liu Xiaoyun, Ma Yujie. Application analysis of DB2 database partition Feature in commercial bank data warehouse [J]. Information Technology and Informatization, 2017(3): 55-58. 